\title{
Ontological (in)Security and African Pentecostalism in Ireland
}

\author{
Mark Maguire ${ }^{a} \&$ Fona Murphy ${ }^{b}$ \\ ${ }^{a}$ Maynooth University, Ireland; ' Queens University Belfast, Ireland
}

abst $r$ act The last number of years has seen the mushrooming of African Pentecostal churches, especially Prosperity Gospel churches, in the post-recession industrial landscapes of Ireland. This article aims to explore the growth of African Pentecostalism in Ireland from both the perspective of embodied and affective religious experience and the conditions for the possibility of those religious experiences. This article is based on several years of ethnographic research among African Pentecostals in Ireland. It attends especially to the sensorious forms of worship and the Jesus walks that Pentecostals organise to transform the Irish symbolic landscape. Drawing on recent anthropological theory, the article draws out the contradictions, doubts, boundaries and limitations perceived and lived in totalising Pentecostal discourses and practices. Here, we develop the concept of ontological (in)security in order to theorise these doubts and limitations as well as the power of contemporary Pentecostalism in late modernity.

keywor ds African Pentecostalism, ontological (in)security, Ireland

Introduction

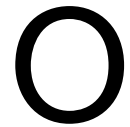

ver a decade ago, an industrial estate composed of warehouses and offices opened adjacent to Glasnevin cemetery, Dublin's 'city of the dead' and one of Ireland's cherished national and religious spaces. This estate, like a great many others, borders a poor neighbourhood and has a transitory and anonymous look. The empty units and redundant machinery testify to the severity of Ireland's recent economic crisis. In these estates, however, one may also witness the extraordinary growth of African Pentecostalism, often in the form of Prosperity Gospel, which encourages spiritual and other investments and attempts to make the world anew. The presence of 
African evangelism in the austere landscapes of late-modern Europe has already attracted considerable anthropological attention (e.g. Maskens 2008; Smit 2009; Blanes 2013; Coleman 2013; Garbin 2013; Krause 2014). Of course, revivalist, charismatic and evangelical forms of Christianity have a long history, and many Pentecostal practices, from glossolalia to energetic testimonies, are old, enduring and remarkably portable. ${ }^{1}$ That said, contemporary Pentecostalism is also marked by late-modern features, and there is important anthropological work situating Pentecostalism amid the dislocations of the current historical moment (see Comaroff 2012a). ${ }^{2}$

This article is based on several years (2008-2013) of ethnographic research among African refugees and asylum seekers in the Republic of Ireland. Estimates suggest that there are over 40,000 Africa-born persons in the Republic, mainly persons born in Nigeria, DR Congo and other west or sub-Saharan countries. National statistics tend to underestimate the numbers of Pentecostals and provide little help in estimating the numbers of African Pentecostals. Several reports conclude that there are approximately 30,000 African 'immigrants' (variously defined) in 'Black Majority churches' (see Irish Council of Churches (ICC) 2003; McGarry 2004; Ugba 2009). The presence of this population is relatively new and coincides with periods of extraordinary economic and social insecurity in Irish history (see Ó Riain 2014).

Over the course of five years of ethnographic research, we worked with many dozens of research participants. Our work was carried out among (predominantly) African Pentecostal congregations in churches such as Christ CoWorkers in Mission and Gospel Faith Mission that were established in Ireland by African migrants without international support. We also carried out research in Mountain of Fire and Miracles Ministry and the Redeemed Christian Church of God (RCCG), which were established deliberately as chapters of broader international movements. We also attended to the lesser presence of 'indigenous' or so-called 'white garment' churches, such as Cherubim and Seraphim and the Celestial Church of Christ, which are often viewed with suspicion by larger congregations. Our initial focus was on Pentecostalism and integration, therefore we studied religious discourses and practices across these churches while acknowledging their sincere theological differences and variations in their religious practices.

As is typical in anthropology projects, we interviewed many research participants formally, and some remained as informal contacts while others became interlocutors and friends. Participants included those baptised into Pentecostalism in Africa together with those who converted during or after the migration 
process. Conversion narratives loomed large in our field notes, with many pastors and individual worshippers reframing their migration journeys in spiritual terms. A sizeable number of our Nigerian research participants, for example, were practising Catholics before conversion to Pentecostalism in Ireland. Conversion narratives spoke of spiritual awakening and the offer of a community of compatriots in a new host'nation-state - a new home in which to feel 'vibrancy and heartbeat', as one interlocutor put it. Many of the churches we explored, such as Mountain of Fire, preached fundamentalist versions of the Gospel and encouraged evangelism. That said, there was also an evident pluralism, shown by the frequency with which fundamentalist churches permitted the newly converted to baptise their children in the Catholic faith to better facilitate integration. Indeed, some of our research participants are practising Catholics or Anglicans who attend 'African churches' after services in Catholic or Anglican ones. 'We don't mind at all', as one Pentecostal pastor explained, 'we see it as: we are under one umbrella. ... We pray and call the same God' (Interview 2012).

It is the tension between totalising Pentecostal world-making and the need to negotiate an often-hostile society of insecurity that motivates this article. This tension is available in the religious practices such as Jesus walks that we describe, walks during which evangelical intent required pluralism in order to simply occur - and, as Kleinman reminds us, Experience is characterised by an orientation of overwhelming practicality' (1999: 360). We aim to tease out tensions in Pentecostal world-making and its late-modern forms through an exploration of ontological (in)security. Drawing from the broad area of phenomenological anthropology (see Desjarlais \& Throop 2011; e.g. Jackson 2009), we use ontological (in)security to conceptually elucidate the tensions in African Pentecostals' lives and sharpen this concept as we do so. And, such tensions are available even in one's first glance at the spatial pattern of Pentecostal churches.

Pentecostal churches regularly operate in spaces such as warehouses that are invisible to a mainstream society that is often perceived to be openly racist. ${ }^{3}$ During evenings and weekends, these warehouses come alive with Gospel music, Bible schools and evangelical sermons; banners announcing a year of prosperity or joy hang on walls next to big-screen TVs and cameras relay ceremonies across the globe. Late-modern Pentecostalism makes available spiritual and other forms of support, social connectivity and even status in a nation-state seen to deny the worshipers as persons. These churches also act in state-like ways, engaging in often mundane but totalising world-making practices that 
are composed of the bodily, affective and spiritual stuff of everyday life - during services, for example, pastors try to elevate congregations and attune them to the presence of the Holy Spirit while mentioning a vacant apartment or visa requirements in another breath. These ostensibly separate kinds of practices are always-emergent sites of transformation and dislocation, constantly shaping the world, being reshaped, thereby encountering different kinds of cultural and ontological limits. To borrow a provocation from Jean Comaroff, Pentecostalism strives for totalisation, concreteness and credibility in an explicit struggle with the threat of falsity, counterfeit, doubt' (Comaroff 2012a: 41). We wish to respond to Comaroff's provocation from the perspective of our ethnographic work. ${ }^{4}$ In short, African Pentecostals in Ireland are engaging in worldmaking discourses and practices amid transformations and insecurities that constantly challenge their credibility and bring into view the (potentially) productive limits of subjects and lifeworlds (see Wittgenstein 1922; James 1996).

We begin by glossing the anthropological literature on Pentecostalism, emphasising the importance of bringing analyses of body practices and broader cultural conditions together. Secondly, we discuss our ethnographic research on pluralist religious walks through symbolic landscapes, walks that cross boundaries and perform multiple ontologies into being. We then tease out matters of ontological (in)security, not as a grand theory of Pentecostalism in late-modern times, but, rather, as a way to attend to specific dimensions of Pentecostalism that we observed as being crucial. Of course, when one speaks of ontological insecurity, one conjures pathological images of the failure of the self and world, doubt and uncertainty (see Laing 1962). We wish to call attention to the (potentially) productive dimensions of (in)security in shaping Pentecostal practice, which in turn shape the insecurities to which they respond. In contrast to those who propose religion as a convenient redoubt in a world beset by precariousness, insecurities and threats to selfhood (see Kinnvall 2004), we use ontological (in)security as a way to explore the growth of Pentecostalism in Ireland by drawing on insights from phenomenological anthropology.

\section{Anthropology and Pent ecostalism}

Robbins (2004; 2009; 2010a; 2010b) draws together the key debates in the fast-growing anthropological literature on Pentecostalism. He notes the vast number of contexts into which Pentecostalism has spread and the strikingly similar cultural and religious processes available, from the epiphanic and revelatory moments to conversion and the active promotion of radical change. 
Indeed, everyday Pentecostal life, rituals and practices, according to Robbins (2010b), are marked by ruptures and rejection of life before conversion. But how might one explore the specific and local at the same time as exploring the pervasive sense of discontinuity and rupture, and all while acknowledging the commonalities found in hard' yet portable forms of Pentecostalism globally?

In a recent article, Josh Brahinsky seeks the key to the above-mentioned issues in the everyday sensory vernacular found among Pentecostal worshipers:

Pentecostal practices ... travel across boundaries - historical, political, denominational - and emerge newly situated while still holding some of their initial shape, although they may be turned sideways or backward. These shifting practices inhabit and help create something thicker and denser; a culture of sensation, or sensorium, a contested realm that nurtures some practices and distinctions while starving, rejecting, or desiccating others. (Brahinsky 2012: 216)

Brahinsky situates this notion of a portable sensorium next to affect theory and advances in neuropsychology and notes the possibility of going beyond the body-mind division of labour that is so redolent of Cartesian modernity (Brahinsky 2012). ${ }^{5}$ But his search for a 'deeper register' is also a thoroughly anthropological effort to locate the culturally specific ways in which bodies are trained and a sensorium is cultivated over time.

This notion of a cultivated sensorium pushes beyond sterile dualisms and objectifications without reducing Pentecostal spirituality to body logics. However, when attending to Pentecostal worshipers' own simplifications, objectifications and rejections of other life possibilities, Brahinsky is in effect arguing for attention to processes of world-making. Indeed, he ultimately turns to questioning how sensory cultures form part of the emergent play between 'realizing expansive imaginaries' and the 'contracting and cementing of possibilities' (Brahinsky 2012: 234). In our work, the conditions for the possibility of this play are found in the everyday lives of African migrants in contemporary Ireland, but also in late modernity itself. Our argument here is that attention to both body practices and the conditions for their possibility calls to mind questions of ontological (in)security.

Recent work by Comaroff (2009; 2012a) offers a useful companion to Brahinsky's meditations on Pentecostal body logics. Comaroff rebels against treatments of Pentecostalism that frame its growth and spread in terms of faiths transposed from one local tradition to another without due consideration of 
the broader conditions of late modernity. Instead, she points to the contemporary rolling back of state-led governance under the star of neo-liberalism, together with the intensifying demolition of the walls separating societal domains - for example, 'the division of institutional labour' between government, religion and the market (Comaroff 2012a: 45). ${ }^{6}$ Neo-liberalism, then, labels more than mere boundary shifting. Structural transformations are apparent and include the emergence of an abstract and high-speed global economic system. The magic and necromancy that Karl Marx once identified in modern capitalism is arguably the hallmark of late-modern Voodoo economics. And, partly because the knowledge produced by traditional institutional labour now lacks plausibility, while the market' offers secular and bloodless (ir)rationality, these structural transformations are opening spaces for popular (often populist, but nonetheless historically rooted) reconfigurations of the relationships between states and citizens, certainty and the civil order, and real and counterfeit. In this context, according to Comaroff, Pentecostal churches seem to exist in a 'cheerful fellowship with the spirit of neo-liberal capitalism' (Comaroff 2009: 18). This is especially well represented by Prosperity Gospel congregations, when on live transnational TV passionately enacted but mundanely scripted prayers are offered for investments and returns. As the internet site of one African church in Ireland puts it, 'We believe that every Christian is a steward of that portion of God's wealth entrusted to him.' Such Pentecostal worshipers, then, do not simply represent the return of faith or its migration to specific locales and domestication therein, but, rather, important transformations of the 'electronic, economic, emotive' (Comaroff 2012a: 47).

Various commentators, including those researching the Irish context, have commented on the ways in which African Pentecostals seem to be, living in a parallel social and moral universe' (Ugba 2009: 124) and note but do not explain the religious capture of functions formerly associated with nationstates and markets. Sincere theological and other differences certainly exist between churches, but research on specific churches has often sealed them into their own particularity. There are important boundary-crossing practices that require attention, and there are important moments such as the Jesus walks that we describe herein that require pluralism in order to be. What Brahinsky (2012: 234) describes as a tension or play between 'expansive imaginaries' and the 'contracting and cementing of possibilities' is the exact point at which developing the concept of ontological (in)security may elucidate ethnographic research on Pentecostalism in Ireland. 


\section{Asylum, Worship and Walks}

The pastor placed his hands on the rain-soaked, medieval gates to the Irish town. Now', he exclaimed, 'you are known to us as the Gates of Heaven!' (Fieldnotes 2011).

During the 1990s, thousands of Africans migrated to Ireland, some to work in the 'Celtic Tiger' economy, while as great many others entered via the refugee and asylum systems (see Ugba 2009). The asylum system 'dispersed' people to regional centres and in so doing diffused Pentecostal churches such as Christ Co-Workers in Mission and Gospel Faith Mission. As we noted earlier, during the late 1990s and early 2000s, African migrants also founded chapters of international churches such as the RCCG and the Mountain of Fire and Miracles Ministry. Moreover, a small number of the so-called indigenous' or 'white garment' churches such as Cherubim and Seraphim and the Celestial Church of Christ were also established. In establishing these churches, refugees, asylum seekers and other migrants realised imaginaries in which asylum is configured as physical and spiritual journeys, and life in a new nation-state thus becomes a religious worldmaking mission. One pastor captured this succinctly: 'Abraham', he reminded us, 'was the first asylum seeker!' (quoted in Maguire \& Murphy 2012a: 112)

African Pentecostalism in Ireland, then, grew in the cold world of administrative order and migration management, a world characterised by forms of precariousness that are understood to be qualitatively distinct from the precariousness that migrants fled. ${ }^{7}$ Today, numbers of asylum seekers are in decline. However, during the 1990s, the numbers of people claiming asylum in Ireland grew at an astonishing rate, peaking at just over 10,000 applications per annum in 2001, and this in a nation-state with a population smaller than that of greater Barcelona (see Mac Éinrí \& White 2008: 153-154). Indeed, the government gave serious consideration to a scheme to house asylum seekers in floating hotels moored in Irish ports. They eventually opted for a system of direct provision via over 50 privatised and semi-privatised shadow villages. Therein, residents are provided with bed and board and E 19.10 per week per adult and E 9.60 per child as they wait until 'status' or deportation ends their time as asylum seekers. Several pastors leading congregations in these shadow asylum villages spoke plainly to us about the crying need for support and hope, and the role of faith in styling persons and their worlds anew. As one pastor explained,

We have an adage from Nigeria that says, 'Well, you want to put a bucket on your head, and you are calling for help? You don't leave it for the person helping you, 
you also support with the hand, and both of you put it off the head.' You know a lot of immigrants have come here, probably they need help; probably they have been subjected to all kinds of attacks, problems, and so on. They also have a part to play in developing where they are. For me, I find everywhere you are is a home, and wherever is a home, you have to make it very good for yourself. So we try to tell them and let them know what have you to contribute to the society. (Interview 2012)

Our research, initially a critique of so-called integration, involved gathering information on asylum seekers and those with refugee status or Ministerial leave to remain' who were residing in the towns near to asylum centres. Most had migrated from volatile and/ or conflict-torn regions of Africa, especially Nigeria and the Democratic Republic of Congo. Some were already energetic Pentecostals while a great many others converted in Ireland and became active in churches as they tried to carve new lives as taxi drivers, parents, activists or business people in a nation-state perceived as Catholic and capitalist yet (oddly) secular and economically bankrupt (see Maguire \& Murphy 2012b). Most of these persons, regardless of their country or origin or conversion experience, held in common experiences of asylum, of long periods warehoused on the edges of life and inevitable threats to their individual credibility and their future security. The faceless and seemingly arbitrary asylum process directly challenges one's being, a challenge crystallised in the official asylum identity cards that state: 'This is not an identity card.' By the 2000s, then, a fast-growing number of Pentecostal congregations were active in the anonymous industrial estates near asylum centres. And, of course, this is not unique to Ireland. Recently, Garbin (2013) noted the growth of Pentecostalism in the gaps of the post-industrial city. A pastor explained it thus,

Industrial estates are a better option than traditional churches. Why is this? W ell, first of all we often have night-long services and activities, and in industrial estates we find we are not disturbing people. ... [But] coming into industrial estates, we found out that we then need to better integrate into the community ... making ourselves known ..., contributing to the local economy. ... We reach out to homeless people and the elderly. [...] In this small estate alone, we are seven Pentecostal churches; in some industrial estates you can have up to fifteen or twenty churches. (Interview 2013)

While no two Pentecostal services are the same even within the same church, it is still possible to describe a 'typical' service in such a way as to draw out salient features. Early one Sunday morning in 2011, for example, we attended 
an international Prosperity Gospel church service in the industrial estate adjacent to Glasnevin cemetery. We joined a large congregation of very welldressed families in the car park, and when the doors of the warehouse opened before us we immediately encountered a sonic wall of Gospel music. The disorientation continued as our eyes adjusted to a massive stage decorated in dazzling colours and a large projection screen displaying images of global services. Worshipers connected with one another, though some were already swaying, entranced by the music. The walls were festooned with flat TV screens beaming Bible quotations, and we nearly knocked over a full-sized television camera on a pivot. That year, according to an enormous banner suspended from the ceiling, was the 'Year of Prosperity'.

As Henri Lefebvre once noted, the Church requires actual churches, because imaginaries are realised in and through space (Lefebvre 1991: 43; see also Knott 2005; Maguire \& Murphy 2012a). ${ }^{8}$ The sheer physicality of our first moments in this Pentecostal church impressed us. Nonetheless, the church could not be described without reference to its transient, electronically nodal and potentially counterfeit features, as if space itself was infused with theatrical manifestations of feeling' (Comaroff 2012a: 49). Our reflections resonate with those of Graham Green at the onset of the Vietnam War. Sensing the groaning fissures opening between worlds in Southeast Asia, Green's attention was captured by the Cao Đài religion in Tay Ninh, with its panoply of eastern and western saints. ${ }^{9} \mathrm{He}$ described this state-like 'W alt Disney fantasia of the East' thus,

Saint Victor Hugo in the uniform of the French Academy with a halo around his tricorn that pointed at some noble sentiment Sun Yat Sen was inscribing on a tablet. ... [T] he marble floor glittered like water and there was no glass in the windows. We make a cage for air with holes, I thought, and man makes a cage for his religion in much the same way - with doubts left open to the weather and creeds opening on innumerable interpretations. (Green 1986: 81-91)

Green wondered about the ways in which the passage of time lends continuity and seriousness to practices one might regard now as implausible and kitsch. His meditations on limitations and doubt strike us as prescient in an exploration of Pentecostalism.

In the warehouse, after an hour's wait, a pastor rushed on stage, dressed in a sharp suit and with a gleaming smile. He listed the books and sections of the Bible relevant to the day's lessons, and as he spoke this image was projected onto the screen behind him, while the Gospel band accompanied his words 
with suitable music. The congregation participated with great enthusiasm, and approximately an hour later two older women volunteered to drive Satan out of us by hitting us on the sides of our heads with Bibles. Seamlessly, the renouncing of the demonic was blended with evangelism, rather mundane community announcements, and impassioned testimonies from congregation members who had converted or were about to be saved. Many of these testimonies narrated the grim features of life in the asylum system or thereafter in a hostile and racialising mainstream society. The insecurity of asylum contrasted with the power and certainty of Pentecostal religious practices that exceed mere words, bodily practices, or even experience, as such. As William James notes, 'Such is the human ontological imagination, and such is the convincingness of what it brings to birth[:] Unpicturable beings are realized, and realized with an intensity almost like that of an hallucination'(James 1906: 72). Following James, contemporary anthropologists attend to 'critical experiences', ontological limits and the morethat surrounds life. And, what really matters, according to Jackson (2009: 101), is not how we name such experiences but, rather, how people live through them.

The rupture of salvation was the point of the life-narratives we listened to and not the unintended consequences of actions during life journeys. The ontological was marked by a dramatic play between security and insecurity, certainty and doubt. Finally, many hours into the service, the star-pastor took to the stage and quickly built up the atmosphere in the room with song and passionate quotation. Tithes were collected; the meeting times for children's Bible school were arranged; passions soared and the congregation was sent out to evangelise Ireland and make it anew. The pastor reminded everyone that they could not really go home, however, because neither their journeys nor their homes could be a profane outside to the sacred island of the church. Everywhere they would encounter limits, self-limitations and doubts. Clearly, then, worshipers went forth facing challenges arising from the need to distinguish between real and fake, the hand of God and the demonic, together with challenges arising from the need to realise imaginaries while recognising the inevitable consequences. Anthropologically, these challenges and tensions are elicited most clearly in the 'Jesus walks' that Pentecostals organise in Irish cities and towns.

Specific forms of Pentecostal walks appeared in London during the late 1980s and quickly spread throughout the western world. In 1994, the first 'Global March for Jesus' was organised to include activities by over 10 million Christians from over 170 nations in every time zone. In 2000, a similar global march 
included an estimated 60 million persons. By the mid-2000s, African Pentecostal churches in Ireland were starting to organise such events. 'Jesus walks' were envisaged as ways to spread the faith, but organisers also aimed at the hearts and minds of mainstream and charismatic Christians and even local residents by emphasising religious efforts to lift Ireland out of economic crisis. These walks were necessarily pluralist, then, even though they were spurred by an evangelist mission. ${ }^{10}$ They were conceived as corporeal engagements with urban space that would reconstitute the symbolic landscape, negotiating, at one and the same time, specific homes in troubled worlds and calling into being a totalising global eamene One junior pastor cast the optimistic agenda plainly, The recession is an act of God. If Irish people start to pray then things will get better. You see in Nigeria things like this don't happen because people pray, people pray and things always get better' (Fieldnotes 2011). Our illustrative description below draws loosely from an ethnographic vignette presented in our larger work (Maguire \& Murphy 2012a). Hereafter, we sift our ethnographic material for insights into matters of ontological (in)security.

In late July 2011, we exchanged notes about a recent Jesus walk through the streets of Drogheda, an Irish border town. We had both been struck forcibly by the experience of marching through Irish streets, dressed in black and white clothing, intoning prayers with African Pentecostals. But we were also struck by how our notes revealed so much through the prism of just one charged moment. On the invitation of a pastor, we rendezvoused very early in the morning near a warehouse-church. After introductions, we began to pray. Immediately, the energy of the group began to rise. The route and protocols were described. We were to visit key sites in the town and would stop at each for prayers, but progress would be silent and respectful to show the solemnity of the walk but also to avoid antagonising the broader community. And, as we moved out from the warehouse to the streets, the desire for sociality competed with the injunction to remain silent. We stopped and prayed at a historical site in the half-darkness, and as the rain poured down the pastor placed his hands on the historic walls to infuse them with His power. But, as we progressed towards the centre of the town we felt the gazes of curious passersby. The procession then stopped outside a branch of a well-known, bailed-out bank - a so-called 'zombie bank', sustained by intravenously injections of capital. We prayed for an intercession by Jesus, that he would rescue the country from the grip of this deep economic recession. Economics was not merely a dismal science but, we were told, a 'doomed' way of living in the 
world. The pastor explained all of this at the top of his voice while the congregation swayed. Satan, he continued, had taken hold in the banks, and our role that day was to pray and drive him out. We did our best, praying, swaying and holding our hands aloft as curious workers unknowingly witnessed an earlymorning exorcism.

Drogheda is dotted with landmarks representing its long and often tumultuous history. At an old military site, a pastor spoke fluently of peace-building. Later, he showed great diplomacy in forewarning the police before staging prayers for law and order, and sprinkling holy oil, outside a station actively investigating 'residual terrorism'. Later still, we prayed outside a local hospital for an end to the severity of health care budget cuts. It was now late morning, and as the long line of 30 or so black and white-clad worshipers snaked through a market area we encountered the first moments of hostility. Most traders just looked amused; some muttered vague insults, and one older man, without a hint of irony, shouted, 'Yez should be off saying yer prayers!'

The Jesus walk involved an evident desire to make the world anew. However, though one might detect a nascent 'solidarity of the shaken' (Patočka 1996: 134), no broad-based solidarity with mainstream society was evident. Again, we call attention to the tensions available between specific world-making practices that project security of belief, the requirements for pluralism and the insecurities of the everyday that condition the projection of belief - the ever-present 'threat of falsity, counterfeit, doubt' (Comaroff 2012a: 41). Thus, our ethnographic questions about powerful, mobile Pentecostal sensoria or the being of Satan in an Irish bank soon turned to ontological questions. However, unlike recent recursive anthropological attention to ontology - a turn that is the subject of much debate (see Henare \& al. 2007; Course 2010; c.f. Bessire \& Bond 2014) - our aim is to simply elucidate the specific ways in which the African Pentecostalism in Ireland vibrates with the conditions of late-modernity and the insecurities that it engenders.

\section{Ontological (in)Security}

Insecurity is fast becoming the leitmotif of the contemporary moment, saturating media and scholarship. Numerous social-scientific studies now track structural transformations in terms of reconfigurations of states, markets and governance and attend to the ramifications in terms of precariousness (see $\mathrm{W}$ acquant 2012; Biehl 2013; Muehlebach 2013) and '(in)securitisation' (see Bigo 2002). Thus, there is a growing interest in ontological (in)security. James (2011: 357), for example, explores societal insecurity and asylum in Haiti, taking ontological 
insecurity to denote an 'existential state reflecting the disordering of individual embodied experience and a collective socio-political condition'. Much of this literature is marked by efforts to bring subjective-level understandings together with evaluations of late modernity, and it traces the concept of ontological (in)security through the work of RD Laing and Anthony Giddens (see Kinnvall 2004; Croft 2012).

Ontological (in)security has many potential meanings and may operate as a 'shifter' (Silverstein 1976) in the cultural dynamics between certainty and doubt, security and fear, knowing and that which exceeds the limits of knowledge. Laing proposed ontological security as existentially self-assured experiences of 'relatedness to other persons and the world' (1962: 67) and built upon developmental psychology to explore the psycho-pathological consequences of 'primary' ontological insecurity. Although some asylum seekers in direct provision fit easily with Laing's descriptions of persons who in the ordinary circumstances of living may feel more unreal than real ...precariously differentiated from the rest of the world' (1962: 42), such were generally the results of violent events fled, harrowing journeys and insecurities engendered by an asylum apparatus characterised by structural violence. Laing's venturesome work focuses on the pathological and lacks detail on the 'interfusion' (Kleinman 1999: 359) of specific discourses and practices with the insecurities of late modernity.

Giddens (1991) also mobilised ontological security by bringing together developmental psychology and Wittgensteinian philosophy. The former spoke to primary ontological distinctions between subjects and things, and the emotional acceptance born of trust that an absent provider will return. The latter body of thought (read in a narrow-gauge fashion) implied the subjective vigilance to guard against anxieties and 'go on' (see 1991: 35-38). At core, then, for Giddens ontological security implies trust in a world that is and will continue to be sufficient to allow someone a 'natural attitude' capable of 'bracketing off' uncertainties and alternatives - 'The natural attitude brackets out questions about ourselves, others and the object-world which have to be taken for granted in order to keep on with everyday activity' (1991: 37). Like Laing, then, Giddens' approach is based on western developmental psychology and an evident ethnocentrism blunts applicability to different cultural configurations or even to the multitudes living their everyday lives amid palpable precariousness and ontological insecurity. ${ }^{11}$ Therefore, one may note a reasonably clear question: what if one focuses more on the Wittgensteinian dimensions of the concept of ontological (in)security as developed by Giddens, on the 
dynamic of security and insecurity, and the determination of people in their everyday lives to 'go on'?

In a recent anthropological dialogue with the work of Ludwig Wittgenstein and Stanley Cavell, Veena Das explores these questions and the very limits of 'ordinary life'. Her starting position is that subjects do not live in worlds that are structured as a coherent whole; rather, their perspectives are levelled upon available horizons and experienced as limited, forever being remade (Das 2007: 4). Moreover, Das adds to our reading of Wittgenstein's philosophy by going beyond communitarian 'forms of life' (Wittgenstein 1968: 19) by emphasising life itself - including the ontological distinctions in that which is recognised as human, fully or politically. To imagine a form of life, then, is to call attention to politics and the penumbral, certainty and scepticism (see Das 2007: 8-9). It is through the very act of bringing together a full analysis of ordinary life that one begins to see how bodily practices and expansive imaginaries encounter limits - and, we propose, ontological (in)security offers important sounding line for the exploration of ordinary Pentecostal life with all its creativity and limitations.

Contemporary work under the broad umbrella of phenomenological anthropological adds greatly to the nascent and as yet underdeveloped concept of ontological (in)security. The concern in this body of scholarship is, as Desjarlais and Throop express it,

[T] ]he existential fact that we are emplaced in a world that always outstrips the expanse of our being. ...A more-than is always woven into the fabric of existence that constantly shifts as we attend to particular aspects of reality, while ignoring others. Uncertainty, ambiguity, and indeterminacy are the norm here. (2011: 90)

Today, in short, it is well recognised that attention to inter-subjective experiences and the sensorious must necessarily also mean attention to broader political, social and historical forces at work in people's lifeworlds. Thus, when one considers diverse migrants who hold in common a faith in expansive and totalising religious world views, researchers confront experiences that are shaped by intersecting lines. On the one hand, there are experiences at the palpable level of the sensorious body, but experiences that are shaped by and in turn interpret and shape broader political, social and historical forces. On the other hand, we not only note the ontological and other forms of security evident in Pentecostal lifeworlds, the expansiveness and textured experiences, but also the variegated, often pluralist but potentially contested negotiations in the everyday. Therefore, we propose that a too-simple equation is offered in socio- 
logical accounts of ontological security: that a secure natural attitude in ordinary life allows for bracketing and thus ontological security. Rather, we find that when ordinary life is itself interfused with insecurities then tensions, limits and (in)securities produce particular forms of 'bracketing' and 'phenomenological modifications' (Throop 2010: passim) that are realised, in our ethnographic example, simultaneously as expansiveness and pluralism, palpable bodily practices and the more of an unfixed ontological world in the making.

\section{Conclusions}

Contemporary anthropological work on global Pentecostalism explores its remarkable expansion by attending to seemingly hard-shelled yet portable sensory body logics that chime with broader structural transformations. This literature eschews framing Pentecostalism as the effortless transposition of a singular faith into multiple locales or as reactive spiritual redoubts in a secular world characterised by 'apparatuses' that outpace sociality. But structural transformation alone offers insufficient insights and runs the risk of 'always and forever only revealing truths that are merely sociological' (Kulick 2014: 26). Rather, Comaroff (2009; 2012a), for example, attends to particular cultural histories together with the broader conditions of late modernity, and the dynamism and creativity of Pentecostalism itself. That said, if one is to propose that Pentecostalism and its practices exist in a 'cheerful fellowship with the spirit of neo-liberal capitalism' (Comaroff 2009: 18), then one must ask: how is that fellowship composed in specific instances?

We have shown the role played by the governmental management of migration in the rise of Pentecostalism among African communities in Ireland. Few are untouched by a system that warehouses people on the edges of society. Describing this system as Kafkaesque does some justice to the deep-felt insecurities it engenders through faceless and seemingly unending processes, such that people are 'stripped of all that is becoming to a man [sic] except his abstract humanity, which, like his skeleton, never is quite becoming to a man' (Trilling 1955: 39). Pentecostalism, then, found fertile ground in the vicinity of asylum centres. Those baptised as Pentecostal Christians in Africa converted asylum seeking into spiritual journeys, and a great many others found power, co-presence and ontological security amid conditions of great insecurity. And, for African refugees or those with leave to remain in Ireland, Pentecostalism manifested itself as the state of modernity rearticulated and reinvested. 
The cultural configurations of Pentecostal churches and their spatial locations therefore chime with the configurations of the world as it is perceived and lived - the 'electronic, economic, emotive' (Comaroff 2012a: 47) - while exceeding that world by pushing towards or beyond its limits though sensory bodily experiences, evangelistic desires and even pluralistic demands. It is such limits and the palpable tensions and dynamic play between ontological security and insecurity that we call attention to here. After all, as William James reminds us, There is a zone of insecurity in human affairs ... of formative processes, the dynamic belt of quivering uncertainty, the line where past and future meet' (James 1956: 125). Our ethnographic attention to Jesus walks suggests confluences of religions practices and world-making discourses in tension with and always pushing against the limits of available horizons. But, we have also asked: how might one conceptually explore these tensions? Herein, we have evoked the concept of ontological (in)security repeatedly, not as an all-explaining theory but, rather, more as a Jamesian sounding line for exploring and charting the importance of contemporary Pentecostalism, structurally as well as bodily and inter-subjectively.

Influenced by William James, phenomenological anthropologists such as Jackson (1983; 1988; 2002; 2009) draw our attention to how people live through experiences during which the taken-for-granted and the penumbral dimensions of life unfold. Nascent but growing discussions of ontological (in)security, we contend, are insufficiently attuned to how people living amid conditions of insecurity 'go on' in productive and even creative ways. As we recorded our observations on the Jesus walk through an Irish border town, our notes filled not only with remarks on bodily and sensory experiences, world-making and hostility, but also with broader questions of how to frame such experiences ethnographically. The Jesus walk held together ideas of spiritual prosperity, pluralistic notions of societal engagement, evangelism and even a scathing critique of the Irish recession in terms of an occult and potentially demonic rupture. Reflecting as a co-participant on the walk, one Pentecostal pastor put it thus,

I read in the scripture this morning that only God can heal the land. It's all because they don't know God, that's why we are here to let them know you can live a good life, a quality life - that all these evil things exist but you can still be happy. (Interview 2012)

But renouncing evils and seeking a quality life may also mean producing a new configuration of late-modern prosperity: 
God is not glorified in churches being poor or people worshipping in a poor church. ... If he owns the whole earth then he is a very rich God, so there is no point preaching holiness and leaving prosperity behind. The thing must be balanced, so there is no holiness without prosperity - that can lead to frustration. (Interview 2012)

Ontological security and insecurity shape everyday experiences for many African Pentecostals who strive for totalisation beset by threats of falsity, and this is reflected in the words of pastors who spoke to us of Prosperity Gospel, that most strikingly late-modern Pentecostal form:

If I, say, earn E 1,000 now, the Lord expects me to give E 100 every month; ...that is where we get money to run the church. Sometimes we can ask the members if we have a project. The good thing is you don't put your money into what you don't see. That is what I was talking about Pentecostal dirtiness: in some places, the people out of their sincere hearts, they give out and then someone somewhere takes the money and uses it for someone else. (Interview 2012)

One goal here is redemption with a healthy financial bottom line produced by tangible returns on investments; but what is at stake here is the tensions and insecurities that cement expansive worlds in the making while limiting and challenging them at the same time. And, the interfusion of the palpable and the abstract becomes sensible in specific and interconnected everyday practices. As Wittgenstein describes the building of certainty - the foundation-walls are carried by the whole house' (1979: 248).

\section{Acknowledgements}

We are grateful to the Irish Research Council for its support.

\section{Disclosure Statement}

No potential conflict of interest was reported by the authors.

\section{Funding}

This research was initially funded by a grant from the Irish Council for the Humanities and Social Sciences (IRCHSS) Research Development Initiative Strand, 2008-2010.

\section{Notes}

1. Estimates suggest that a half billion persons globally can be categorised as Pentecostal worshipers - over $40 \%$ of whom reside in sub-Saharan Africa (see Pew Report 2011). 
2. Several commentators (e.g. Coleman 2013; c.f. Marshall 2009) argue that Pentecostalism must not be treated as superficial mystifications of contemporary life. But it remains important to attend to the growth of 'new' religious pradices coeval with structural transformations, and there is a long-standing body of scholarship on this topic (see Worsley 1968).

3. Although connections exist between Pentecostal churches across the island of Ireland, the history of Pentecostalism in the Republic and Northern Ireland is significantly different, and we cannot attest to spatial patterns in Northern Ireland (see Murphy 2002; Ugba 2009). Our focus is on the dominant pattern of locating churches in industrial warehouses. Recently, one Dublin local authority 'discovered' over 20 churches in a routine survey of industrial estates and courted controversy by threatening worshipers with eviction on the grounds of breaches of planning and health and safety regulations (see Colfer 2013).

4. We discuss the late modern' herein in ways that track the work of Comaroff and Comaroff (2012). They do not take the late modern to denote a Euro-American telos; rather, they aim to explore the Hydra-headed process of contemporary capitalism and the multi-focal points at which it may be perceived, conceived and lived and from which it may be written about. Their approach has its critics. Marshall (2009: 27-28), for example, questions the notion that Pentecostal practices respond to contemporary neoliberal confusions, or 'a growing sense of radical insecurity'. Comaroff (2012b), of course, rebuts the accusation of a-historicism. However, Marshall's critique may also be read as a call for scholars to go beyond broad theories of the contemporary and instead show how particular Pentecostal practices emerge and are made meaningful.

5. The contemporary 'affective turn' is the subject of a great many disciplinary literatures. For many, affect denotes the embodied physiological and cognitive responses to the significance found in the world and the learning and recall potential of humans (see Neuman \& al. 2007: 9; Brown \& Seligman 2009). In the hands of philosopher Massumi (2002), it is open and pre-mediated, a way of exploring human physicality while remaining a metaphysical concept attuned to that which exceeds the human. However, anthropologists remain suspicious of pre-subjective or unmediated notions of culture and affect's resemblance to older concepts such as 'passion' (see Mazzarella 2009; Comaroff 2012).

6. This chimes with Michel Foucault's well-known observation that the processes that subsist behind neo-liberalism include the apotheosis of a concept of a competitive market capable of socialising individuals and enabling their continuous selfstyling. The market, thus configured, becomes a 'permanent economic tribunal confronting government' (Foucault 2008: 247; see also Maguire \& Murphy 2014).

7. There is a substantial body of scholarship on global Pentecostalism that attends to its flourishing in contexts of socio-economic and political precariousness (see Robbins 2004; 2009). However, it is not sufficient to propose that religious forms simply reply to the precariousness of life' (see Butler 2004: 25, 49, 134-135) as a general condition of the world. African refugees and asylum seekers certainly paint pictures of precariousness pre-migration, often speaking of structural violence tearing the fabric of everyday life or violence claiming loved ones or whole communities (see Maguire \& Murphy 2012). But the flourishing of African Pentecostalism in 
Ireland is intimately tied to the asylum system and thus to specific, qualitative conditions. Ireland warehouses asylum seekers in direct provision often for up to seven or more years; it has one of the highest rejection rates for asylum claims in Europe and has been censured by the UN Committee against Torture. During 2014, residents in several direct provision centres went on hunger strike demanding decisions on their claims and an end to the system. The responsible agency, the Reception and Integration Agency (RIA), remains defiant and acknowledges the deterrent function of the system. Speaking at a recent conference in Dublin, a high-level RIA representative told the audience that the I' in RIA was in fact 'silent'. Thus, pastors and worshipers described the importance of churches in and nearby direct provision centres in spiritual and qualitative sociological terms - the specific temporal, spatial and emotionally impactful dimensions of the system required churches precisely because of hopeful, involved and expansive world-making practices that addressed Being-in-the-world.

8. As Knott (2005) has observed, scholars draw from Lefebvre when addressing the social constitution of relational space as that which holds together and enfolds different dimensions of life (see Lefebvre 1991: 404). But one may also note the intriguing ontological questions he raises. In his celebrated discussion of monuments that enclose social relations in 'texture', he notes that they fail to 'achieve a complete illusion', because their 'credibility is never total' (1991: 221-223 passim). He notes that spatial (monumental) work offers a horizon of meaning' but proposes that the very openness of those horizons, the potentially indefinite meanings and shifting hierarchies are all suggestive of a 'totality' that exceeds the everyday - in Jamesian terms, a more that rings the limits of life (1991: 222).

9. Cao Đài ‘officially' revealed Himself as Ngoc-Hoàng Thuong-De viet Cao-Dai giaodao Nam-Phuong to séance-going Vietnamese bureaucrats who were inspired by the international wave of 'table-turning' efforts to commune with spirits during the 1920s. The groups séances were spiritually crowded affairs marked by the presences of such luminaries as Joan of Arc, Sun Yat-sen, Rene Descartes and Victor Hugo, the latter going on to become a saint in the Cao Đài Spiritual Pope's department of overseas affairs.

10. This pluralist coming together of Pentecostal churches for Jesus walks seemed at first glance to temporarily suspend tensions between different versions of faith and society. More properly, we later understood, the particular nature of the walks brought those very tensions into play, elevating these practices beyond any mundane, spatial and political enactments of belonging. Earlier in our work (Maguire \& Murphy 2012) we recorded moments in which some African migrants called for symbolic walks to protest issues of race in Irish towns, but others demurred. Jesus walks were distinct cultural forms: they were open and pluralist, yet evangelising and claiming to directly speak to 'the spirit' of societal concerns, and all while avoiding the gaze of and confrontation with mainstream society. These tensions can be explored in terms of ontological (in)security.

11. Giddens displays a strikingly parochial sense of ontological security when he pushes towards issues such as performativity. 'All human beings', he tells readers, in all cultures, preserve a division between their self-identities and the "performances" they 
put on in specific social contexts' (1991: 58). The list of anthropologists who would disagree is long indeed, and Clifford Geertz provides an eloquent summation of such theories of 'Mr Natural':

Whatever else modern anthropology asserts - and it seems to have asserted almost everything at one time or another - it is firm in the conviction that men modified by the customs of particular places do not in fact exist, have never existed, and most important, could not in the very nature of the case exist. There is, there can be, no backstage where we can go to catch a glimpse of Mascou's actors as 'real persons' lounging about in street clothes, disengaged from their profession, displaying with artless candour their spontaneous desires and unprompted passions. They may change their roles, their styles of acting, even the dramas in which they play; but - as Shakespeare himself of course remarked - they are always performing. (Geertz 1973: 35)

\section{References}

Bessire, Lucas \& David Bond. 2014. Ontological Anthropology and the Deferral of Critique. American Ethnologis, 41(3):440-456.

Biehl, João. 2013. Vita: Lifein a Zone of Social Abandonment. Berkeley: University of California Press.

Bigo, Didier. 2002. Security and Immigration: Towards a Critique of the Governmentality of Unease. Alternatives 27:63-92.

Blanes, Ruy. 2013. Prophetic Visions of Europe: Rethinking Place and Belonging among Angolan Christians in Lisbon. In Stes and Pditics of Reigious Diversty in Southern Europe, edited by Ruy Blanes and José Mapril. pp. 51-72. Leiden: Brill.

Brahinsky, Josh. 2012. Pentecostal Body Logics: Cultivating a Modern Sensorium. Cultural Anthropdogy, 27(2):215-238.

Brown, Ryan \& Rebecca A. Seligman. 2009. Anthropology and Cultural Neuroscience: Creating Productive Intersections in Parallel Fields. Progress in Brain Research, 178:31-42.

Butler, Judith. 2004. Precarious Life The Powers of Mourning and Videnœ London and New York: Verso.

Coleman, Simon. 2013. Only (Dis-)Connect: Pentecostal Global Networking as Revelation and Concealment. Religions, 4(3):367-390.

Colfer, Colette. 2013, August 24o. Places of W orship. The Irish Times p. 7.

Comaroff, Jean. 2009. The Politics of Conviction: Faith on the Neoliberal Frontier. Social Analysis, 53(1):17-38.

2012a. Pentecostalism, Populism, and the Politics of Affect: In Africa and Elsewhere. In Penteostalism and Develgpment: Churches NGOsand Social Changein Africa, edited by Dena Freeman. pp. 41-67. London: Palgrave Macmillan.

.2012b. Religion, Society, Theory. Religion and Sodedy: Advanoes in Reearch, 3:5-34.

Comaroff, Jean \& John Comaroff. 2012. Theory from theSouth or, How Euro-America isEvdving toward Africa. Boulder, CO: Paradigm Publishers. 
Course, Magnus. 2010. Of W ords and Fog: Linguistic Relativity and Amerindian Ontology. Anthropdogical Theory, 10(3):247-263.

Croft, Stuart. 2012. Constructing Ontological Insecurity: The Insecuritization of Britain's Muslims. Contemporary Seaurity Policy, 33(2):219-235.

Das, Veena. 2007. Lifeand Words Videnœeand theDesønt intotheOrdinary. Berkeley: University of California Press.

Desjarlais, Robert \& Jason C. Throop. 2011. Phenomenological Approaches in Anthropology. Annual Revien of Anthropdogy, 40:87-102.

Foucault, Michel. 2008. TheBirth of Biopditics L eduresat theCollegedeFranœ, 1978-1979. London: Palgrave Macmillan.

Garbin, David. 2013. The Visibility and Invisibility of Migrant Faith in the City: Diaspora Religion and the Politics of Emplacement of Afro-Christian Churches. Journal of Ethnic and Migration Sudies 39(5):677-696.

Geertz, Clifford. 1973. The Interpreation of Cultures New York, NY: Basic Books.

Giddens, Anthony. 1991. Modernity and Sedf-identity: Self and Sociey in theL ateM odern Age Cambridge: Polity Press.

Green, Graham. 1986. The Quiđ American. New York, NY: Penguin Books.

Henare, Amira, Martin Holbraad \& Sari W astell. 2007. Thinking Through Things Theorizing Artefads Ethnographically. London: Routledge.

Irish Council of Churches. 2003. Researdh Prgied into Aspeds of the Religiaus Life of Refugees Asylum Sedkersand Immigrantsin theRepublic of Ireand. Belfast: Irish Council of Churches. Jackson, Michael. 1983. Thinking Through the Body: An Essay on Understanding Metaphor. Social Analysis, 14:127-148.

_ 1988. Paths towards a Clearing: Radical Empiriasm and Ethnographic Inquiry. Bloomington: Indiana University Press.

2002. The Politics of Storyteling: Videnœ, Transgression, and Inter-subjectivity. Copenhagen: Museum Tusculanum Press.

2009. ThePalmat theEnd of theMind: Relatedness, Religiosity, and the Røal. Durham, NC: Duke University Press.

James, William. 1906. The Varieies of Reigions Experienœ A Study in Human Nature London: Longmans, Green and Co.

1956. TheWill toBdieveand Other Essayson Popular Philosphy and Human Immorality. New York, NY: Dover Publications.

- 1996. A Pluralistic Universe Hibbert Lecturesat Mandhester Collegeon the Present Situation in Philœsphy. Lincoln, NE: University of Nebraska Press.

James, Erica C. 2011. Haiti, Insecurity, and the Politics of Asylum. Medical Anthropology Quarterly, 25(3):357-376.

Kinnvall, Catarina. 2004. Globalization and Religious Nationalism: Self, Identity, and the Search for Ontological Security. Pditical Psydhology, 25(5):741-767.

Kleinman, Arthur. 1999. Experience and its Moral Modes: Culture, Human Conditions, and Disorder. In The Tanner Leđures on Human Values edited by G.B. Peterson. pp. 357-420. Salt Lake City: University of Utah Press.

Knott, Kim. 2005. Spatial Theory and Method for the Study of Religion. Temenos 41(2):153-184.

Krause, Kristine. 2014. Space in Pentecostal Healing Practices among Ghanaian Migrants in London. Medical Anthropdogy, 33(1):37-51. 
Kulick, Don. 2014. Merely Sociological. Sodal Anthropdogy, 22(1):25-27.

Laing, Ronald David. 1962. The Divided Sdf: An Existential Study in Sanity and Madness

New York, NY: Pantheon Books.

Lefebvre, Henri. 1991. TheProdudion of Space London: Blackwell.

Mac Énrí, Piaras \& Allen White. 2008. Immigration into the Republic of Ireland: A Bibliography of Recent Research. Irish Geography, 41(2):151-179.

Maguire, Mark \& Fiona Murphy. 2012a. Integration in Ireand: The Everyday Lives of African Migrants Manchester: Manchester University Press.

2012b. Boundaries of the State and Politics of Everyday Life in Ireland. Anthropdogy News, 53(2):6-7.

2014. Neo-liberalism, Securitization and Racialization in the Irish Taxi Industry.

European Journal of Cultural Studies, 17(3):282-297.

Marshall, Ruth. 2009. Pditical Spiritualities ThePenteostal Revdution in Nigeria. Chicago, IL: University of Chicago Press.

Maskens, Maité. 2008. Migration et Pentecôtisme à Bruxelles. Ardhives deSaienœes Sociales des Religions, 3(143):49-68.

Massumi, Brian. 2002. Parablesfor theVirtual: Movement, Affeet, Sensation. Durham: Duke University Press.

Mazzarella, William. 2009. Affect: What Is It Good For? In Enchantments of Modernity: Empire, Nation, Gldbalization, edited by Saurabh Dube. pp. 291-309. London: Routledge.

McGarry, Patsy. 2004, February 25. Immigrants Praised for 'Huge Impact' on Church'. The Irish Times p. 4.

Muehlebach, Andrea. 2013. On Precariousness and the Ethical Imagination: The Year 2012 in Sociocultural Anthropology. American Anthropologist, 115(2):297-311.

Murphy, Liam D. 2002. Demonstrating Passion: Constructing Sacred Movement in Northern Ireland. Journal of the Sociey for the Anthropology of Europe, 2(1):22-30.

Neuman, Russell, George E. Marcus, Michael MacKuen \& Ann N. Crigler. 2007. The Affed Effed: Dynamics of Emotion in Pditical Thinking and Behaviour. Chicago, IL: University of Chicago Press.

Ó Riain, Seán. 2014. The Riseand Fall of Irdand's Cettic Tiger: Liberalism, Boom and Bust. Cambridge: Cambridge University Press.

Patočka, Jan. 1996. Hereical Essaysin thePhilosophy of History. Chicago, IL: University of Chicago Press.

Pew Report. 2011. Gldbal Christianity: A Report on theSizeand Distribution of the World's Christian Population. London: The Pew Forum on Religion and Public Life.

Robbins, Joel. 2004. The Globalization of Pentecostal and Charismatic Christianity. Annual Review of Anthropdogy, 33:117-143.

2009. Pentecostal Networks and the Spirit of Globalization: On the Social Productivity of Ritual Forms. Social Analysis, 53(1):55-66.

-2010a. Anthropology, Pentecostalism, and the New Paul: Conversion, Event, and Social Transformation. South Atlantic Quarterly, 109(4):633-652.

2010b. Anthropology of Religion. In Sudying Gldbal Penteoosalism Theories and Mehods edited by Allen Anderson. pp. 156-178. Berkeley: University of California Press. Silverstein, Michael. 1976. Shifters, Verbal Categories and Cultural Description. In Meaning in Anthropdogy, edited by Keith Basso and Henry Selby. pp. 11-57. Albuquerque, NM: School of American Research. 
Smit, Regien. 2009. The Church Building: A Sanctuary or a Consecrated Place? Conflicting Views Between Angolan Pentecostals and European Presbyterians. African Diaspora, 2:182-202.

Throop, C. Jason. 2010. Suffering and Sentiment: Exploring theViaissitudes of Experienœand Pain in Yap. Berkeley: University of California Press.

Trilling, Lionel. 1955. The Opposing Sdf. London: Secker \& W arburg.

Ugba, Abel. 2009. Shades of Belonging. African Pentecotals in Twenty-first Century Ir land. Trenton, NJ, Asamara, Eritrea: Africa World Press.

Wacquant, Loïc. 2012. Three Steps to a Historical Anthropology of Actually Existing Neoliberalism. Sodial Anthropdogy, 20(1):66-79.

Wittgenstein, Ludwig. 1922. Tradatus Logio-Philœophias London: Routledge \& Kegan Paul.

— 1968. Philosphical Investigations New York, NY: Macmillan. 1979. On Certainty. Oxford: Basil Blackwell.

Worsley, Peter. 1968. The Trumpet Shall Sound: A Sudy of 'Cargo Cults' in Melanesa. New York, NY: Schocken Books. 